\title{
Phosphatidic Acid
}

National Cancer Institute

\section{Source}

National Cancer Institute. Phosphatidic Acid. NCI Thesaurus. Code C68415.

A glycerol backbone covalently bound to a phosphate group in one position, and fatty acids in the 2 nd and 3 rd positions. Phosphatidic acids thus have a polar head and apolar tails, and occur in cell membranes throughout nature. 